\title{
Amelioration of Violence in Tertiary Institution in
}

\section{Nigeria}

\author{
DOSUNMU, Simeon .A. (PhD) \\ $\&$ \\ AROMOLARAN, Adedayo. B. \\ Department of Educational Foundations \& Counselling Psychology, \\ LAGOS STATE UNIVERSITY, OJO, LAGOS
}

\author{
Accepted: November 02, 2012 Published: December 17, 2012 \\ Doi:10.5296/ijld.v2i6.2883 URL: http://dx.doi.org/10.5296/ijld.v2i6.2883
}

\begin{abstract}
There is no doubting the fact that eruption of violence in most tertiary institutions nowadays is as a result of dwindling social relationship and loss of cultural values. The unsatisfying consequence therefore, has really taken its toll on the overall development of the educational sector. This paper examines violence in tertiary institution and proffer solutions that will in no small measures reawaken cultural values.
\end{abstract}

\section{Introduction}

The society is created for necessary interactions of individuals, groups in order to facilitate and enhance overall growth as well as general development of such individuals and groups and the larger society. Individuals in any society one way or the other relates together on various issues, most especially as it affects members within the group using different or various means in doing all this. The structural functionalists emphasized the coming together of individuals in every existing society towards building strong and dynamic institutions where members' interests are well taken care off.

There is need for every of the sub-systems such as economic, social, education, politics, to work towards the functioning and survival of the whole system. This is done through maximum cooperation and collaborations of all in the drive to establish a peaceful and highly conducive society devoid of unhealthy rivalries, conflict and act of disorderliness.

Parsons (1951) cited in Haralambos \& Holborn (2004) started with the question of how social order is possible. He observed that social life is characterized by mutual advantage and peaceful cooperation, rather than hostility and destruction.

The concept of function in functionalist analysis refers to the contribution of the parts to the whole. More specifically, the function of any part of society is the contribution it makes to meet the functional prerequisite, and functional as far as they maintain the system and contribute to its survival. Thus, a function of the family is to ensure the continuity of society by reproducing and socializing new members, a function of religion is to integrate the social function or social system by reinforcing common values; while school inculcates the knowledge and norms of the society into the pupils or students.

Schools of today are not the same as they were. At present, schools have lots of violence and physical abuses than in a fight club. The reported cases of theft, one student inflicting pain on 
another student, gang wars and so on are on the high these days. All these acts of misconduct are generally referred to as school violence. Well, such small acts of misconduct can be tolerated, but these days, violence has gone to such a high extremity that students who have not even crossed their adolescence are not afraid to handle a gun or a knife. They are quite ready to screw their fellow mates when a rift of some sort arises among them.

It is indeed very disturbing to see such acts of misconduct in a noble and a divine place like schools. However, one cannot deny or oppose the fact that such terrible things are happening in most schools across the world and especially the United State of America (Gilligan, 1996).

Like charity, violence begins at home. As Gilligan observed, 'the use of violence as a means of resolving conflict between persons, groups and nations is a strategy we learn first at home', (1996).

People first learn to use violence as a strategy for resolving conflicts in their homes. This forms part of all overall strategies for dealing with everyday living. It can indeed be said that no existing family can claim exemption from experience of violence either as a perpetrator or a victim.

\section{The Concept of Violence}

Life is dynamic and so nothing in it is static. Dynamism of life is what makes it interesting, challenging and puzzling. Though it is often said that nothing is new under the heavens, but it must be said that old things are usually painted in new colours, or given new names, status or appear in a new way or dimension and as such is regarded new. Every society started from the primitive state and keeps on changing until it reaches full modernization. As such, things keep on changing until there is nothing to change, but a kind of reappearance, recording or re-colouring of old things in the modern time.

The school life in the society is dynamic as well. It does not remain static for life. For example, in the primitive society, school life was peaceful and calm. However, in the developing society, school life is not as peaceful. A lot of changes in form of acts of indiscipline such as violence are features of schools in the developing society.

Protecter (1980) defines violence as a very great force in action or feeling or rough treatment. Brehm, S, Kassim, S, \& Fein, S (2002) sees violence as an extreme act of aggression. Violence has its root in aggression. Aggression is seen by some as behaviour that is intended to injure another person who does not want to be injured.

Smith (2000) observes that: "violence has always been part of the political process... protest activities of one form or another, efforts to dramatize grievances in a fashion that will attract attention and ultimately the destruction or threatened destruction of life and property appear as expression of political grievances even in stable, consensual societies... the ultimo ratio of political action is force",

Violence is also synonymous with hooliganism. The most synonymous form of hooliganism is celebratory violence that includes riots after sporting events (e.g. tearing down of goal posts and property destruction, outside of the sports grounds), at parties such as in the end of the year or session, and at other school events (Coakley \& Donnelly 2004).

Violence or threat of violence is a universal phenomenon. It has been used by groups seeking power, holding or losing power. Violence has been pursued in the defense of order by the privileged, in the name of justice by the oppressed, and in fear of displacement by the threatened.

Several theorists have come to recognize violence and the threat of violence as a dimension of both national and international politics. Thus, Smith (1968) cited in Banjo (1997) observes that; 
"violence has always been part of the political process... protest activities of one form or another, efforts to dramatize grievances in a fashion that will attract attention and ultimately the destruction or threatened destruction of life and property appear as expression of political grievances even in stable, consensual societies... the ultima ratio of political action is force'".

The word 'violence' defies any precise definition that is commonly accepted; the concept often serves as all variety of protest, militancy, coercion, destruction or muscle flexing which a given observer happens to fear or condemn. The frequent conceptualization of force and violence tends to confuse the legality and legitimacy of specific acts. Force is often taken to mean legal and legitimate use of violence by a government for the protection of the state, while violence is interpreted as illegal and illegitimate acts carried out by non-governmental individuals and groups.

Violence to Henry (1968) cite in Banjo (1997) carries overtones of violability and we use often violence to refer to illegitimate force ... but the state according to Weber (1974) as stated in Banjo (1997) is the exclusive source of the right to use violence all other individuals or associations may use it only to the degree permitted by the authorities.

Stanko (1999) observes that "we usually associate violence and its use with individually motivated action, although a great deal of violence is committed by individuals on behalf of others". Violence is also associated with vehemence, impetuosity, destructiveness, turbulence, uproar, rough handling, brutality, terrorism, brute force, thuggery and, cruel act.

Violence is an act of wickedness; that is wickedness in thought and personified in human relations. It is man's inhumanity to man.

\section{Causes of Violence}

There are many reasons that can lead to eruption and creation of violence among individuals, groups and existing community or society. Prominent among these are the house environment, easy availability of weapons, depression and anxiety, lost of love and affection, support from people and career.

House environment- If the parents or guidance are constantly fighting with each other and are using abusive language at home then children will learn it as well. They will practice these things in schools and will trouble other students and teachers.

Availability of weapons- In this era, weapons are easily available through illegal means. Children buy these weapons from illegal sources and use them in schools to threaten or to bully other children. They even use these weapons to kill other people as well.

Depression and Anxiety- Any kind of stress, tension and anxiety can lead to violence among children. If they are under severe depression then it may be possible that they can express their depression by becoming violent. This violence can include anything like theft, rape, bullying and killing other people.

Absence of Love and Affection- If a child is not given proper love and affection then he or she can become violent.

Absence of Necessary Support- If teachers are not helping the child during difficulties then the child will get frustrated and this frustration can lead to violence. So, it is the duty of the teachers to lend a helping hand to the students.

Career- If a child is unable to decide what he or she wants in life or if he or she is not sure about his or her future, then the chances of becoming violent is more. Violent attitude will not only create problems to other students and teachers but it will destroy the child's career as well. So if you want to save children from becoming violent then you can take the help of career counselor 
as well. They are specialized people and are having full knowledge; they know about the career aspects and growth available in every sector.

\section{Violence in the School}

It is not a strange incidence in the school. It is as common as any other offence. It is one of such acts of disregarding and disrespecting the constituted or governing authority through disposition of negative behaviours as a way of expressing views on an issue over which an agreement could not be reached.

School violence, according to a new study by the international Bureau of Education is increasing at an alarming rate worldwide (Ohsako, 2001). Contrary to what is commonly through, school violence is as much an issue in developing countries as industrialized ones; in rural areas as much as in urban neighborhood.

The display of violence is not limited to higher institutions of learning, but to some extent like umbilical cord attached to a baby so is the exercise of violence in both primary and secondary schools.

\section{Causes of School Violence}

Violence engendering divisions in Nigeria go beyond ethnic, religion and political spheres. Divisions are also based on educational qualification whether it is the quest for such qualifications or possessing of certificate attesting to success. Tertiary education qualifications serve as a measure of economic success as well as prestige. For instance, children of educated parents must obtain educational qualifications at least commensurate with those of their parents. In general, to have less education than one's parent is considered to constitute eternal disgrace to family honour and to oneself. Because education still represents the direct and prestigious path to social status, both parents and wards strive to obtain it by all means. This means that parents and other older relatives lent their blessings and assistance to examination malpractice.

Many students in our secondary schools as well as the parents complain of high cost of fees compared with situations, most especially at the privately-owned schools, increased cost of books, miscellaneous expenditure and so on. Understandably, secondary school teachers complain of student overcrowding, insufficient facilities, poor student quality and escalation of malpractice tendencies among students. All these do not make for school peaceful coexistence between students and teachers. It is therefore not surprising that students' beating and fighting of individual teachers is fast increasing in our educational institutions all over the country.

Violence in school could be associated with so many other factors aside the fundamental factor of loss in our cultural values and ideas; such other factors or reasons could be access to weapons, media violence, cyber abuse, the impact of school, community, and family environments, personal alienation, inadequate support and guardian, worry and stress, hostile teachers and classroom, and more.

One factor that may explain the problem of violence is our young generation's early exposure to violence. Many adolescents are exposed to violence at an early age, very often in their homes, either by witnessing it first hand in family altercations, or by watching it on television or on DVDs.

As children assimilate violence in the form of entertainment, they become desensitized to pain and suffering. They become anesthetized to trauma. Most of all, they become insensitive to the consequences of ego serving rage, the kind that endows the villain with power and 
invincibility. Even as Hollywood entices its audience with unmitigated acts of violence, it purges these acts of all moral parameters.

Adolescent minds come away from the screen believing that power justifies all, even murder. Many begin imitating their screen hero by intensifying their desire to live raging. Others who are themselves the victims of violence and bullying become trapped in the cycle of brutality.

Another factor is the lack of parental attention in many homes. One can find equally valid arguments for (and examples of) close nurturing families that grow stronger during times of hardship. In fact, the best in human character surfaces during periods of want and suffering. It is not poverty that creates the criminal because poverty has also created Presidents and Nobel Laureates.

It is the choice that parents make, the choice not to give their children the attention they deserve; and this is a choice that has been made both under dire circumstances and during the best of times.

\section{Effects of Violence in the School}

School violence has increasingly becoming a menace and as such its negative effects on educational and societal development. It has been causing so many havocs that if nothing is done to urgently address it, so many more life and property are at stake each time it rear its ugly head.

It is noteworthy to emphasize that many family had been brought to untold hardship and agony through the killings, harming, raping, bullying, theft and many other wickedness being perpetrated by these gang of students.

Below are some of the worries being created as a result of act of violence in the school :

1. Parental Worries: The worries of the parents could somehow be understandable. It is the pride of all parents that their child is one among the best and not among the rogues, gangs or murderers. Imagine bidding your child bye-bye to school in the morning only to be called upon hours later that same child had been killed, hurt or been hurt.

2. School Reputation Eroded: The school authority or administrator that had labour over the years to acquire a reputable name for the school could hardly hide their helplessness while watching those reputations being rubbish in the course of school violence. It is most likely that lots of parents will prefer to withdraw their children from such schools, while admission of the new entrants become scanty.

3. Violent children are hindering the school growth and development of many innocent students. In the process of finding solution, the school is close down, even after it had been reopen, fear possible re-occurrence rents the air, thereby causing many other students to lose concentration on their studies.

4. Peaceful and Serene environment is momentarily distorted. Anxiety and wailing atmosphere replaces where used to be a citadel of learning and where the supposed leaders are trained.

5. Killing and Bloodshed: The number of lives that had lost in school violence either directly or indirectly cannot be accurately counted. The brutality of gang students claimed many lives of students and teachers.

6. Violent students and gangs are playing kite with their tomorrow if at all they have any. Children who could have been the pillars and shakers of the society have suddenly turned wayward. 
7. Nation's Pride and Growth: No responsible government is happy seeing her citizen wasting other peoples' life or being wasted. It is an act of lawlessness and shameful act to read or hear that those who are suppose to pick the mantle of leadership tomorrow have turned miscreants or been killed. In addition, the future of that country or nation is hanging in the balance unless some drastic measure is taken to return the situation to normalcy.

\section{Theoretical Framework}

The conflict theorists do not see a great deal of consensus, harmony, or cohesion in contemporary society. They see groups with competing and clashing interests and values. They see struggles between and among categories, sectors, groups, and classes in the society, with winners and losers resulting from the outcome of these struggles.

Most social institutions, they argue, do not benefit the society as a whole. Rather, they benefit some group at the expense of others. Conflict theorists envision the resources of the society as being distributed according to a "zero sum game", that is, they are of a fixed size, and whatever is distributed to one faction or category is taken away from another.

The conflict theorists said for the existence of different interests, the potential for, and likelihood of conflict is always present. Different groups pursuing their separate interests are likely to clash and produce some degree of instability in the society. The theorists agreed that the existence of groups with different interests does not mean that they will be in conflict all the time. There may be periods of truce, or it may be that some social groups are persuaded that their interests are not different from those of other groups.

Nevertheless, periods of harmony does not last forever, and eventually conflict will return. The views expressed here by those in the conflict group that is, the conflict theorists such as Karl Marx, Max Weber and so on, in a wider sense explains the occurrences of crisis in every existing society as a result of diverse interests; members of various or different groups or associations, organizations, peers, age-groups in the society, even at the school level, tend to emphasize considerations for group members' views at the expense of opposition. While doing this, conflict thus evolve in form of fights, violence, arguments, vandalization and distruption of peace and harmony within and outside the school environment.

In summary of conflict theory, Ian Crab (1984) describes it in the following way:

'Society is like a more or less confused battle ground. If we watch from on high, we can see a variety of groups fighting each other, constantly forming, and reforming, making and breaking alliances'.

\section{Conclusion}

Conclusively, as explained and expressed by the functionalists; the society must continue in its developmental process, given consideration to involvement of every individual via proper integration to the societal set principles.

\section{Suggestions}

From the discussions above, the following suggestions are made to ameliorate violence in our tertiary institutions:

- Efforts at emphasizing the teaching and recognition of societal moral values by our teachers at all levels of education. 
- Accurate connectivity between the school and the home; thus, enhancement and promotion of good teaching and learning in an environment that is devoid of unnecessary crisis.

- Structuring of the educational system in such a way that it benefits every students (individuals).

- There is need for recognition of views or opinions of the students; as regards positive requests made towards making their stay in the school system relevant and worthwhile.

- Proper integration of the students into admitting the societal demands and expectations in respects of norms and dispositions which is germaine to peaceful co-existence.

- An all involving educational policies that cater for educational needs of everybody not minding race, sex, age, and status.

- Adequate and necessary measures should be put in place for curbing act of violence by relevant authorities; such as disciplinary measure.

- An enabling environment gives rooms for proper learning; thus, the need for the stake holders in our educational development to provide such

- Democratization of governance in the school system promotes peaceful relationship between the authority and the students, and between communities and schools. This democratization implies the creation of an institutional design that could pave way for involvement of teachers, parents, students and the administrators in the undertaking of decisions necessary in the school system.

\section{References}

Banjo, W (1997) Nigeria: Political Violence In The Third Republic: African Research Bureau Monograph Series, Vol 1, No 1, Afrab Publishers, Lagos.

Brehm, S, Kassin, S \& Fein, S (2002) Social Psychology: New York, Houghton Mifflin Company.

Coakley, J \& Donnelly, P. (2004) Sport in Society: Issues and Controversies. Toronto, Canada. McGraw Hill.

Gilligan, J (1996) Violence: Refflections on a National Epidemic. New York: Vantage Books. Haralambos M, \& Holborn M. (2004): Sociology, Themes \& Perspectives; London, Harper Collins Publishers Limited.

Jones, S. (2001): Criminology, $2^{\text {nd }}$ ed. Butterworths London.

Ohsako, T (2001) Violence at School: Global Issues and Interventions, IBE UNESCO, Paris. Protecter, P (1980) Longman Dictionary of Contemporary English, International Student Edition, England: Longman Group Ltd.

Stanko, E.A (1999) "Violence"' in K. Adam \& K, Jessie (ed, 1999) The Social Science Encyclopaedia, Second Edition. London: Routhledge.

Smith, B (2000) 'The Politics of Violence: How Effective is Violence'" in Proceedings of the Academy of Political Science. Pp. 111-120 